\title{
Detection and Quantification of Xanthomonas albilineans by qPCR and Potential Characterization of Sugarcane Resistance to Leaf Scald
}

\author{
F. F. Garces, A. Gutierrez, and J. W. Hoy, Department of Plant Pathology and Crop Physiology, Louisiana State University Agricul- \\ tural Center, Baton Rouge 70803
}

\begin{abstract}
Garces, F. F., Gutierrez, A., and Hoy, J. W. 2014. Detection and quantification of Xanthomonas albilineans by qPCR and potential characterization of sugarcane resistance to leaf scald. Plant Dis. 98:121-126.

Leaf scald is an important disease of sugarcane with erratic symptom expression. Latency represents a threat to germplasm exchange, and erratic symptom development makes accurate evaluation of disease resistance during breeding and selection problematic. Real-time quantitative polymerase chain reaction (qPCR) assays for Xanthomonas albilineans, the causal agent of leaf scald, were developed and evaluated for the sensitive, specific detection and quantification of the pathogen. Assays with SYBR Green primers and TaqMan probe and primers derived from the albicidin toxin biosynthesis gene cluster efficiently and reproducibly amplified $X$. albilineans. Detection was more sensitive with qPCR compared with conventional PCR. Assays

were specific for $X$. albilineans and sap extracts did not inhibit the qPCR reaction. Leaf-scald-resistant and -susceptible cultivars were distinguished by infection incidence, disease severity, and $X$. albilineans population determined by SYBR Green GPCR in both greenhouse and field experiments. Populations of $X$. albilineans varied in different tissues. Differences were the greatest within tissues in resistant cultivars, and bacterial populations in systemically infected, young, not yet fully emerged leaves exhibited the greatest differences between resistant and susceptible cultivars. The results demonstrate that qPCR is a highly sensitive method for the detection of $X$. albilineans that could provide a reliable method for leaf scald resistance screening.
\end{abstract}

Leaf scald of sugarcane (Saccharum spp. hybrids) is a systemic, vascular bacterial disease that can cause severe yield reductions, eliminate potential cultivars, and pose quarantine concerns for germplasm exchange. Leaf scald has been reported in more than 66 countries (21) and was first detected in Louisiana in 1993 (12). Widespread distribution resulted from the exchange of symptomless, infected vegetative germplasm (seed-cane) in the absence of adequate detection techniques in quarantine programs $(3,25)$. Latent symptoms in susceptible cultivars also can result in the distribution of infected seed-cane within sugarcane production regions.

Several methods have been developed to detect and identify the leaf scald causal agent, Xanthomonas albilineans (Ashby) Dowson, including selective media, microscopy, serologically based, and polymerase chain reaction (PCR)-based techniques $(1,4,5,10,13$, 15-17,27). These techniques have been used to detect infection, differentiate strains of $X$. albilineans, index seed-cane, and assay germplasm in quarantine for exchange $(1,2,8,13,15,26)$. However, detection of $X$. albilineans in asymptomatic plants can be problematic with any of the detection methods.

Host plant resistance is the primary method of leaf scald control $(19,21)$. The most common method used to discriminate different levels of resistance is through inoculation of decapitated plants (14), in which shoots are cut above the apical meristem and inoculum is applied to the cut surface. Cultivar reaction is then evaluated according to some combination of observed levels of disease incidence and severity. Different arbitrary rating systems have been proposed using qualitative information based on the type of symptoms and the quantity of plants with different symptom types (23). However, the erratic nature of leaf scald symptom expression even in inoculated tests makes screening for resistance a difficult task. Environmental stress conditions affect symptom severity in natu-

Corresponding author: J. W. Hoy, E-mail: jhoy@agcenter.lsu.edu

Accepted for publication 7 August 2013.

http://dx.doi.org/10.1094/PDIS-04-13-0431-RE

(C) 2014 The American Phytopathological Society rally infected plants, inoculation success, and the severity of symptom expression after inoculation (19).

Bacterial population at the shoot apex determined by quantification on semiselective medium was associated with leaf scald resistance level in sugarcane clones varying in susceptibility (23). This suggests the possibility of a resistance screening method based on the quantification and comparison of $X$. albilineans populations in different clones.

Real-time, quantitative PCR (qPCR) is a highly sensitive, reproducible, and accurate method that is being used for qualitative and quantitative analysis of nucleic acid molecules $(9,11)$. The potential for high sensitivity and specificity could make qPCR a superior method for reliable detection of $X$. albilineans in all of the situations described previously. If the relationship between $X$. albilineans population dynamics inside the plant, symptom severity, and resistance level is confirmed, $X$. albilineans quantification with qPCR could provide a more reliable method for determining resistance levels in sugarcane genotypes in inoculation tests. The objectives of this study were to develop qPCR assays for $X$. al bilineans and determine the potential for detection, bacterial population quantification, and leaf scald resistance screening.

\section{Materials and Methods}

DNA extraction. A lysis boiling method was used with leaf vascular exudates and stem xylem sap samples to extract bacterial DNA in sterile, distilled, deionized water $\left(\mathrm{sdH}_{2} \mathrm{O}\right)$. The Qiagen DNeasy Plant Mini Kit for DNA extraction (Qiagen Inc.) was used for extraction from apical meristem samples.

Leaf exudates and sap from the stem were transferred to $1.5-\mathrm{ml}$ tubes for extraction. After centrifugation at $9,000 \times g$ for $5 \mathrm{~min}$, the supernatant was discarded, and the bacterial pellets were suspended in $100 \mu \mathrm{l}$ of lysis buffer. After vortex mixing, samples were incubated at $95^{\circ} \mathrm{C}$ for $10 \mathrm{~min}$ in a water bath. The DNA from the meristem was extracted by macerating $100 \mathrm{mg}$ of tissue in a universal BIOREBA extraction bag of 12 by $14 \mathrm{~cm}$ (BIOREBA AG) containing $1.5 \mathrm{ml}$ of AP1 buffer from the Qiagen DNeasy plant mini kit. DNA was extracted using the kit according to the manufacturer's guidelines. Total DNA extracted by each method was quantified using a NanoDrop spectrophotometer (Thermo Fisher Scientific). 
Primer and probe design. Six different sets of primers were designed from the $X$. albilineans genome sequence $(18,24)$ using the program Beacon Designer (Premier Biosoft International; 7). The gene cluster of albicidin biosynthesis corresponding to the $a l b \mathrm{I}$ gene, the nonribosomal polyketide synthase NRPS-1/3 module, and the A4-A5 region (GenBank accession number AJ586576) (24) were targeted for $X$. albilineans specific primers. A TaqMan Double-Quenched Probe (5'FAM/ZEN/3'ABkFQ) with two quenchers, $\mathrm{ZEN}$ and $\mathrm{ABkFQ}$, and the FAM reporter was developed following the manufacturer's instructions (IDT Integrated DNA Technologies). After blasting the sequences, all the primer sets were tested using a 10-fold dilution series prepared from an initial suspension of $X$. albilineans with $3.4 \times 10^{7} \mathrm{CFU} / \mathrm{ml}$.

Conditions of amplification for conventional, SYBR Green, and TaqMan PCR. Conventional PCR. Following the conventional PCR protocol of Davis et al. (5), a 2- $\mu$ l aliquot from each DNA extract was mixed with $12.5 \mu$ of GoTaq master mix $(2 \times$; Promega BioSciences), $0.1 \mu \mathrm{l}$ of each forward and reverse primer (Xalb2 primer set; $100 \mu \mathrm{M}$; Integrated DNA Technologies), 10.16 $\mu \mathrm{l}$ of $\mathrm{sdH}_{2} \mathrm{O}$, and $0.14 \mu \mathrm{l}$ of bovine serum albumen fraction $\mathrm{V}$ (100 $\mu \mathrm{g} / \mu \mathrm{l})$ for a final volume of $25 \mu \mathrm{l}$. The conditions of amplification were as follows: an initial step at $94^{\circ} \mathrm{C}$ for $4 \mathrm{~min}$; followed by 31 cycles of DNA denaturation at $94^{\circ} \mathrm{C}$ for $30 \mathrm{~s}$, annealing at $55^{\circ} \mathrm{C}$ for $30 \mathrm{~s}$, and polymerization at $65^{\circ} \mathrm{C}$ for $3 \mathrm{~min}$; and a final extension at $65^{\circ} \mathrm{C}$ for $3 \mathrm{~min}$.

SYBR Green PCR. From each sample of DNA, $2 \mu$ was mixed with $7.5 \mu \mathrm{l}$ of SYBR Green master mix $(2 \times), 0.1 \mu \mathrm{l}$ of each forward and reverse primer (100 $\mu \mathrm{M}$; Integrated DNA Technologies), and $5.3 \mu \mathrm{l}$ of $\mathrm{sdH}_{2} \mathrm{O}$ (7). The conditions of amplification (7) were as follows: an initial step at $95^{\circ} \mathrm{C}$ for $10 \mathrm{~min}$ followed by 40 cycles of DNA denaturation at $94^{\circ} \mathrm{C}$ for $10 \mathrm{~s}$ and annealing-polymerization at $60^{\circ} \mathrm{C}$ for $30 \mathrm{~s}$. The melting curve analysis consisted of 81 cycles with stepwise increases in set point temperature after cycle 2 by $0.5^{\circ} \mathrm{C}$ from 55 to $95^{\circ} \mathrm{C}$ for $30 \mathrm{~s}$. A 10 -fold dilution series of $X$. albilineans DNA extracted from a $10^{7} \mathrm{CFU} / \mathrm{ml}$ suspension was diluted five or six times to be used as standards with concentrations from $10^{7}$ to $10^{2} \mathrm{CFU} / \mathrm{ml}$ to determine the qPCR amplification efficiency, cycle threshold value $\left(\mathrm{C}_{\mathrm{T}}\right)$, and concentration of the unknown samples.

TaqMan PCR. From each sample of DNA, $2 \mu \mathrm{l}$ was mixed with $10 \mu \mathrm{l}$ of TaqMan universal master mix (Roche), $1 \mu \mathrm{l}$ of each forward and reverse primer $(10 \mu \mathrm{M})$ and TaqMan double-quenched probe XaQ ( $2 \mu \mathrm{M}$; Integrated DNA Technologies), and $5 \mu \mathrm{l}$ of $\mathrm{sdH}_{2} \mathrm{O}$ for a final volume of $20 \mu \mathrm{l}(7)$. The conditions of amplification (7) were as follows: an initial step at $50^{\circ} \mathrm{C}$ for $10 \mathrm{~min}$ and a second step of $95^{\circ} \mathrm{C}$ for $2 \mathrm{~min}$, followed by 40 cycles of DNA denaturation at $94^{\circ} \mathrm{C}$ for $15 \mathrm{~s}$ and annealing-polymerization at $60^{\circ} \mathrm{C}$ for $1 \mathrm{~min}$.

Positive control samples for all PCR experiments were diffusates from leaves collected from plants showing symptoms of leaf scald that previously tested positive for $X$. albilineans. Negative control samples were diffusates from noninfected plants. A no-template sample consisting of purified water was always included. All controls were added to the reaction plate in triplicate wells for all experiments.

Evaluation of qPCR detection specificity and sap extract inhibition. Experiments were conducted to determine the specificity of $X$. albilineans detection using both SYBR Green and TaqMan PCRs. Bacteria isolated from sugarcane xylem sap, including Asaia bogorensis, Gluconacetobacter liquefaciens, Herbaspirillum rubrisubalbicans (causal agent of mottled stripe), Leifsonia xyli subsp. xyli (causal agent of ratoon stunt), Pantoea ananatis, Tanticharoenia sakaeratensis, other bacteria, Burkholderia gladioli and Xanthomonas oryzae, and one common epiphytic fungus, Cryptococcus albidus, were tested for amplification. Cultures of organisms isolated from sugarcane sap and DNA of other bacteria were provided by M. Grisham and K. Warnke (United States Department of Agriculture-Agricultural Research Service [USDAARS] Sugarcane Research Unit, Houma, LA). Identifications were obtained by amplification with universal primers and sequencing.
In addition, three randomly selected, unidentified bacteria growing on XAS selective medium (Wilbrink's agar medium modified with $5 \mathrm{~g}$ of potassium bromide, $100 \mathrm{mg}$ of cycloheximide, $2 \mathrm{mg}$ of benomyl, $25 \mathrm{mg}$ of cephalexin, $30 \mathrm{mg}$ of novobiocin, and $50 \mathrm{mg}$ of kasugamycin) (4) after inoculation with sugarcane xylem sap were tested for amplification. Three replicate samples prepared by the lysis boiling method were tested in two experiments. DNA concentrations for samples of six $X$. albilineans isolates were 60 to 155 and 87 to $536 \mathrm{ng} / \mu \mathrm{l}$ for the other bacteria and the fungus, respectively.

The potential for sugarcane sap extract inhibition of $X$. albilineans amplification during qPCR was evaluated in samples obtained from the lysis boiling extraction method by comparing amplification of three known $X$. albilineans concentrations suspended in a 10 -fold dilution series of water or extracts from leaves of four sugarcane cultivars: 'LCP 85-384', 'HoCP 85-845', 'HoCP 89846', and 'Ho 95-988'. Three replicate samples were tested in two experiments each for SYBR Green and TaqMan PCRs.

Greenhouse and field experiments. Replicated, inoculated greenhouse and field experiments were conducted. Four sugarcane cultivars were used in both greenhouse and field experiments: LCP 85-384, HoCP 85-845, HoCP 89-846, and Ho 95-988. Two additional cultivars, 'HoCP 96-540' and 'HoCP 00-950', were included in field experiments. According to average ratings determined from evaluation of symptom severity following inoculation in multiple field experiments and field observations of natural infection, LCP 85-384, Ho 95-988, and HoCP 96-540 were resistant, HoCP 00950 was moderately susceptible, and HoCP 85-845 and HoCP 89846 were susceptible (J. Hoy, unpublished).

Bacteria for inoculum were isolated from a longitudinal section of the leaf that included a pencil-line symptom. Tissue was surface sterilized with $\mathrm{NaOCl}(0.5 \% \mathrm{vol} / \mathrm{vol})$ for $30 \mathrm{~s}$ and rinsed two times with $\mathrm{sdH}_{2} \mathrm{O}$. The leaf sections were dried in a laminar flow hood, cut in small pieces 1 to $2 \mathrm{~mm}$ wide, and placed in a $1.5-\mathrm{ml}$ microcentrifuge tube (Eppendorf) containing $1 \mathrm{ml}$ of $\mathrm{sdH}_{2} \mathrm{O}$. The tube with infected tissue was left overnight at $4^{\circ} \mathrm{C}$. A loop of bacterial suspension was transferred to XAS selective medium with antibiotics (4) (Wilbrink's medium that contains $5 \mathrm{~g}$ of Bacto Peptone, $10 \mathrm{~g}$ of sucrose, $0.5 \mathrm{~g}$ of $\mathrm{K}_{2} \mathrm{HPO}_{4} \cdot 3 \mathrm{H}_{2} \mathrm{O}, 0.25 \mathrm{~g}$ of $\mathrm{MgSO}_{4} \cdot 7 \mathrm{H}_{2} \mathrm{O}$, and $0.05 \mathrm{~g}$ of $\mathrm{Na}_{2} \mathrm{SO}_{3}$ per liter supplemented with $25 \mathrm{mg}$ of cephalexin, $30 \mathrm{mg}$ of novobiocin, $50 \mathrm{mg}$ of kasugamycin, $100 \mathrm{mg}$ of cycloheximide, $2 \mathrm{mg}$ of benomyl, and $5 \mathrm{~g}$ of $\mathrm{KBr}$ ). After 5 to 8 days, single colonies were selected to obtain pure cultures on solid XAS medium without antibiotics. Pure cultures were incubated at $28^{\circ} \mathrm{C}$ and, after $48 \mathrm{~h}, 5 \mathrm{ml}$ of $\mathrm{sdH}_{2} \mathrm{O}$ was added to each plate. The suspended $X$. albilineans colonies were diluted to obtain $10^{8} \mathrm{CFU} / \mathrm{ml}$ based on spectrometric absorbance $(0.18$ optical density at $590 \mathrm{~nm}$ ) and direct colony counting on XAS medium. The inoculum was kept at $4^{\circ} \mathrm{C}$ in the dark prior to inoculation. In both greenhouse and field experiments, approximately 2-month-old plants were inoculated using the decapitation method (14). Plants were inoculated by pipetting $100 \mu \mathrm{l}$ of bacterial suspension onto the surface of a cut made above the apical meristem with scissors also dipped in the inoculum suspension.

In all, 8 to 20 plants per cultivar were inoculated in greenhouse experiments using a randomized design. Plants in single-row plots, $2 \mathrm{~m}$ in length, planted with two stalks and with two replicates per cultivar, were inoculated in field experiments. All inoculations were done at the end of the day at about sunset.

In greenhouse experiments, $X$. albilineans detection was compared in leaves of different ages, the apical meristem, and the stem base for LCP 85-384, HoCP 85-845, HoCP 89-846, and Ho 95-988 to evaluate bacterial population variability and determine the best tissue for detecting differences in resistance among cultivars. The leaves collected were the youngest fully emerged leaf, commonly designated in sugarcane as the top visible dewlap (TVD) leaf, the second younger leaf above the TVD (TVD-2) and the third older leaf below (TVD+3). Leaf, meristem, and stem base samples were collected from 8 to 20 individual plants 10 weeks after inoculation (wai). 
In greenhouse and field experiments, $X$. albilineans populations quantified in the TVD-2 leaf by SYBR Green qPCR were compared with conventional screening for leaf scald resistance based on incidence of infection and systemic symptom severity. In the field experiments, leaves were collected in composite samples of three to five leaves, with three to five composite samples collected from each of two 2-m plots at 8 wai.

All samples from the greenhouse and field were collected in plastic bags and kept at $4^{\circ} \mathrm{C}$ until processing. In all experiments, 20 leaf discs were collected from each leaf using a 5-mm-hole paper punch, with nine discs from the lamina on each side of the midvein. The discs were placed together in a $1.5-\mathrm{ml}$ microcentrifuge tube containing $1 \mathrm{ml}$ of $\mathrm{sdH}_{2} \mathrm{O}$. Between samples, the paper punches were surface sterilized by dipping in $95 \%$ ethanol and flaming. A 7-cm-long section from the base of the stem was excised using sterilized clippers. The vascular sap was extracted in a $50-\mathrm{ml}$ tube by centrifugation at $3,500 \mathrm{rpm}$ for $5 \mathrm{~min}$ and transferred to a $1.5-\mathrm{ml}$ sterile microcentrifuge tube.

Samples from the meristem and surrounding tissue were collected from the shoot apex by peeling off fully emerged leaves and collecting $100 \mathrm{mg}$ of tissue that included the apical meristem and not-yet-emerged apical leaf tissue. Samples were kept at $4{ }^{\circ} \mathrm{C}$ during the DNA extraction procedure to reduce tissue oxidation. For bacterial streaming, the tissue was chopped and transferred to a microcentrifuge tube whereas, for genomic DNA extraction, 100 mg of tissue was homogenized, as described previously.

Disease assessment. Disease severity in the greenhouse and field experiments was evaluated at the same time that qPCR samples were collected according to the type of symptoms observed and number of stalks exhibiting different symptom types in each plant using a formula (23). Severity was evaluated according to the type of symptom observed in each plant using the formula: DS = $[(1 \times \mathrm{FL}+2 \times \mathrm{ML}+3 \times \mathrm{CB}+4 \times \mathrm{N}+5 \times \mathrm{D}) / 5 \times \mathrm{T}] \times 100$, where multiplication factors 1 to 5 increasingly weight the number of stalks with more severe systemic symptom types as follows: $\mathrm{FL}=$ number of stalks with leaves exhibiting one or two narrow, white, pencil-line streaks; $\mathrm{ML}=$ number of stalks with more than two pencil-line streaks in leaves; $\mathrm{CB}=$ number of stalks with leaf chlorosis or bleaching; $\mathrm{N}=$ number of stalks with leaf necrosis; $\mathrm{D}$ $=$ number of dead stalks or stalks with side shooting; and $\mathrm{T}=$ total number of stalks.

Data analysis. $X$. albilineans populations were quantified by qPCR through introgression of the positive samples average on the standard curve determined by linear regression of the known $X$.

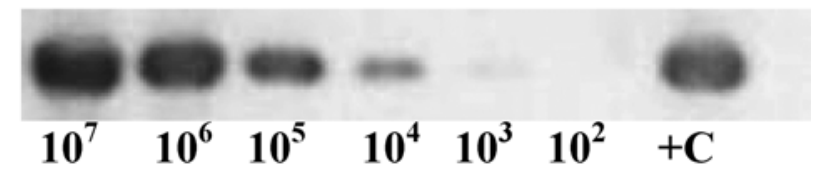

Fig. 1. Conventional polymerase chain reaction amplification of a Xanthomonas albilineans 10-fold dilution series from a suspension of $10^{7} \mathrm{CFU} / \mathrm{ml}$ exhibiting (from left to right) positive amplification with $10^{7}, 10^{6}, 10^{5}, 10^{4}$, and $10^{3}$ but not with $10^{2}$ dilutions, and a positive control $(+C)$. The positive control consisted of leaf diffusate from an $X$. albilineans-infected plant. albilineans concentration dilution series. $X$. albilineans population and leaf scald incidence and severity data were analyzed using the Proc GLM procedure of SAS (SAS Institute, Inc.). Experiment and cultivar-experiment interactions were not significant; therefore, data from repeated experiments were combined for mean comparisons. For treatment comparisons, minimal significant differences for means were established according to Tukey's at $P \leq 0.05$. Means for bacterial concentrations determined by qPCR were compared rather than $\mathrm{C}_{\mathrm{T}}$ values.

\section{Results}

SYBR Green, TaqMan, and conventional PCR amplification of $\boldsymbol{X}$. albilineans. The highest amplification efficiency $(\geq 97 \%)$ was observed for SYBR Green with primer set XAprF6 5'-CGA GCA GGT GAA GGA CAG-3' and XAprR6 5'-GCG ATG GCA CTA GGT ACA G-3', and for TaqMan with XaQ probe 5'/56-FAM/CGT CAC CTG/ZEN/CCA TTG CTC AAT CGC C/31ABkFQ/-3' and primers XaQr 5'-GCG ATG GCA CTA GGT ACA GC-3' and XaQf 5'-TTT GCG GTG TCG GTA AAG GAG-3'. For SYBR Green PCR, the single peak of fluorescence associated with a DNA fragment of $98 \mathrm{bp}$ showed a single melting point of $82.5^{\circ} \mathrm{C}$. The TaqMan PCR produced a 148-bp product. The TaqMan XaQ probe and SYBR Green primer set showed threshold $C_{T}$ values of 15.4 to 17.0 and 32.2 to 33.5 , respectively, for the entire range of six 10 fold standard dilutions of a $10^{7}$ bacterial concentration. The standard curves of the SYBR Green primer set and the TaqMan XaQ probe showed a high reproducibility between replicates of the standards with $\mathrm{C}_{\mathrm{T}}$ standard deviation values of 0.03 to 0.2 and 0.09 to 0.94 , respectively, with successful detection for all dilutions. The standard curve y-intercept of the SYBR Green and TaqMan PCRs showed values for the theoretical "1-copy" detection limit of 43.7 and $42.2 \mathrm{C}_{\mathrm{T}}$ values, respectively. In contrast, the conventional PCR did not detect the lowest dilution of $10^{2} \mathrm{CFU} / \mathrm{ml}$ (Fig. 1).

Detection specificity and sap inhibition. No amplification occurred with SYBR Green and TaqMan qPCRs when DNA extracted from bacteria isolated from sugarcane xylem sap, including A. bogorensis, G. liquefaciens, $H$. rubrisubalbicans, L. xyli subsp. $x y l i, P$. ananatis, T. sakaeratensis, and three other unidentified bacteria; from $B$. gladioli and $X$. oryzae; and from one fungus, $C$. albidus, were used as a template, while DNA from six $X$. albilineans isolates was amplified.

Extracts from leaves of the four sugarcane cultivars LCP 85-384, HoCP 85-845, HoCP 89-846, and Ho 95-988 did not affect amplification by either qPCR comparing five concentrations of a 10-fold dilution series of $X$. albilineans as determined by sap extract bacterial suspension differences from the water suspension control $\mathrm{C}_{\mathrm{T}}$ value of less than $1 \mathrm{C}_{\mathrm{T}}$ (Table 1 ).

Disease incidence and severity. Symptoms developed initially in inoculated leaves of both resistant and susceptible cultivars. Inoculated leaves of all four cultivars exhibited chlorosis, pencillines, yellow chlorotic streaks, or necrosis of the tissue from the edge of a cut leaf toward the base of the leaf 2 to 3 wai. At 8 to 16 wai, the new, emerged leaves of different cultivars showed variable amounts of systemic chronic symptoms of infection, including pencil-lines, leaf chlorosis or bleaching, shortening of internodes,

Table 1. Comparison of amplification of Xanthomonas albilineans DNA diluted in water and sap extracted from four sugarcane cultivars using SYBR Green and TaqMan polymerase chain reaction assays

\begin{tabular}{|c|c|c|c|c|c|c|}
\hline \multirow[b]{3}{*}{ Cultivar ${ }^{\mathrm{Z}}$} & \multicolumn{6}{|c|}{ Cycle threshold values for three bacterial DNA concentrations with two assays ${ }^{y}$} \\
\hline & \multicolumn{2}{|c|}{$3.5 \mathrm{E}+4$} & \multicolumn{2}{|c|}{$3.5 \mathrm{E}+6$} & \multicolumn{2}{|c|}{$3.5 \mathrm{E}+8$} \\
\hline & SYBR-Gr & TaqMan & SYBR-Gr & TaqMan & SYBR-Gr & TaqMan \\
\hline Water control & 32.6 & 35.8 & 23.0 & 28.3 & 21.4 & 24.2 \\
\hline LCP85-384 & 32.7 & 35.0 & 23.2 & 28.8 & 21.9 & 23.4 \\
\hline НоCP85-845 & 33.0 & 34.8 & 23.4 & 29.6 & 21.6 & 23.7 \\
\hline НоСР89-846 & 33.4 & 35.9 & 23.1 & 28.4 & 21.9 & 23.8 \\
\hline Ho95-988 & 33.3 & 36.8 & 23.0 & 29.3 & 22.0 & 23.3 \\
\hline
\end{tabular}

\footnotetext{
${ }^{y}$ Amplification of DNA extracted from three concentrations of $X$. albilineans CFU using SYBR Green and TaqMan polymerase chain reaction assays.
}

${ }^{\mathrm{z}}$ Bacterial DNA diluted in healthy leaf sap from four sugarcane cultivars prepared with DNA extraction procedure. 
abnormal lateral shoot growth, leaf necrosis, wilting and curling of leaves, and death of shoots. The incidence of plants exhibiting symptoms of systemic infection and severity scores for those plants clearly differentiated the cultivars into the expected resistant and susceptible groups under both greenhouse and field conditions. Incidence and severity were generally lower in the field compared with the greenhouse experiments.

Comparison by qPCR of $X$. albilineans populations in different tissues of resistant and susceptible cultivars. The $X$. albilineans population detected by qPCR varied in different tissues and between resistant and susceptible cultivars (Table 2). Bacterial populations were four orders of magnitude greater in leaves emerging after inoculation in the susceptible HoCP 85-845 and HoCP 89-846 compared with the few positive samples from the resistant LCP 85-384 and Ho 95-988 (Table 2).

The $X$. albilineans population was high in leaves of three different ages and in the meristem and stalk of the susceptible cultivars, ranging from $10^{5}$ to $10^{9} \mathrm{CFU} / \mathrm{ml}$ (Table 2). More variation was detected among tissues for the resistant LCP 85-384 and Ho 95988 , with populations of $10^{2}$ to $10^{6} \mathrm{CFU} / \mathrm{ml}$. The greatest difference between resistant and susceptible cultivars was detected in the new emerging, systemically infected TVD-2 leaf, with four to five orders of magnitude difference in population levels between re- sistant and susceptible cultivars. The incidence of positive $X$. albilineans detection by qPCR was 100 and $85 \%$ for HoCP $89-846$ and HoCP 85-845, respectively, compared with 10 and 5\% for Ho 95-988 and LCP 85-384, respectively.

Comparison of $X$. albilineans population quantified with qPCR and leaf scald severity and incidence between resistant and susceptible cultivars in greenhouse experiments. Lower bacterial population levels and fewer infected samples detected by qPCR corresponded with low disease severity and incidence in the two resistant cultivars (Table 3). Ho 95-988 and LCP 85-384 had only 17 and $8 \%$ qPCR positive samples, respectively, with $X$. albilineans populations of $10^{2} \mathrm{CFU} / \mathrm{ml}$ in the plants with positive detection, no systemic symptoms in LCP 85-384, and pencil-line symptoms in $10 \%$ of Ho $95-988$-inoculated plants. In contrast, the incidence of detection by qPCR was 79 and $100 \%$ for HoCP 89 846 and HoCP 85-845, respectively, with high $X$. albilineans populations of $10^{6} \mathrm{CFU} / \mathrm{ml}$, a high incidence of systemic symptom development, and severe symptoms, including several chlorotic streaks that coalesced to form large chlorotic or bleached areas and necrosis.

Comparison of $X$. albilineans population quantified with qPCR and leaf scald severity and incidence in resistant and susceptible cultivars in field experiments. $X$. albilineans popula-

Table 2. Quantification of Xanthomonas albilineans population by SYBR Green quantitative polymerase chain reaction (qPCR) in different tissues of two leaf-scald-resistant and two susceptible sugarcane cultivars in the greenhouse ${ }^{y}$

\begin{tabular}{|c|c|c|c|c|c|c|c|c|}
\hline \multirow[b]{3}{*}{ Tissue $^{\mathrm{z}}$} & \multicolumn{4}{|c|}{ Resistant cultivars } & \multicolumn{4}{|c|}{ Susceptible cultivars } \\
\hline & \multicolumn{2}{|c|}{ LCP 85-384 } & \multicolumn{2}{|c|}{ Ho 95-988 } & \multicolumn{2}{|c|}{ HoCP 85-845 } & \multicolumn{2}{|c|}{ НоСР 89-846 } \\
\hline & $\mathbf{C}_{\mathrm{T}}$ & CFU/ml & $\mathbf{C}_{\mathrm{T}}$ & CFU/ml & $\mathbf{C}_{\mathrm{T}}$ & CFU/ml & $\mathbf{C}_{\mathrm{T}}$ & $\mathrm{CFU} / \mathrm{ml}$ \\
\hline Apical meristem & 26.0 & $3.6 \mathrm{E}+4$ & 25.1 & $7.9 \mathrm{E}+4$ & 23.7 & $7.3 \mathrm{E}+5$ & 22.0 & $1.7 \mathrm{E}+6$ \\
\hline Leaf (TVD-2) & 34.8 & $3.8 \mathrm{E}+2$ & 32.1 & $3.1 \mathrm{E}+3$ & 17.6 & $1.6 \mathrm{E}+7$ & 19.4 & $1.5 \mathrm{E}+7$ \\
\hline Leaf (TVD) & 34.0 & $6.2 \mathrm{E}+2$ & 26.5 & $1.8 \mathrm{E}+6$ & 19.3 & $7.3 \mathrm{E}+6$ & 20.3 & $5.5 \mathrm{E}+6$ \\
\hline Leaf (TVD+3) & 34.0 & $6.2 \mathrm{E}+2$ & 25.5 & $8.6 \mathrm{E}+5$ & 16.4 & $1.6 \mathrm{E}+7$ & 20.2 & $6.6 \mathrm{E}+6$ \\
\hline Stem base & 27.9 & $2.1 \mathrm{E}+6$ & 31.2 & $1.0 \mathrm{E}+4$ & 16.1 & $2.9 \mathrm{E}+7$ & 20.9 & $1.3 \mathrm{E}+6$ \\
\hline
\end{tabular}

y Cycle threshold $\left(\mathrm{C}_{\mathrm{T}}\right)$ average value for $\mathrm{qPCR}$ and $X$. albilineans $(\mathrm{CFU} / \mathrm{ml})$ detected by $\mathrm{qPCR}$.

${ }^{\mathrm{z}}$ Meristem with primordial leaf tissue. TVD-2 = second leave above the youngest fully emerged leaf or top visible dewlap (TVD) leaf and TVD+3 $=$ third leave below the TVD leaf. Xylem sap extracted from the stem base.

Table 3. Comparison of Xanthomonas albilineans populations determined by SYBR Green quantitative polymerase chain reaction (qPCR) in emerged leaves of two susceptible and two resistant sugarcane cultivars with conventional leaf scald resistance screening in greenhouse experiments ${ }^{\mathrm{w}}$

\begin{tabular}{|c|c|c|c|c|c|}
\hline \multirow[b]{2}{*}{ Cultivar $^{\mathrm{z}}$} & \multicolumn{3}{|c|}{ qPCR results ${ }^{x}$} & \multicolumn{2}{|c|}{ Conventional screening ${ }^{y}$} \\
\hline & Incidence (\%) & $C_{T}$ value & CFU/ml & Severity score & Incidence (\%) \\
\hline HoCP 85-845 (S) & 100 & 20.5 & $7.8 \mathrm{E}+6 \mathrm{a}$ & $74 \mathrm{a}$ & $100 \mathrm{a}$ \\
\hline НоCР 89-846 (S) & 79 & 21.1 & $5.1 \mathrm{E}+6 \mathrm{a}$ & $82 \mathrm{a}$ & $85 \mathrm{a}$ \\
\hline LCP 85-384 (R) & 8 & 34.3 & $8.7 \mathrm{E}+2 \mathrm{~b}$ & $0 \mathrm{c}$ & $0 \mathrm{c}$ \\
\hline Ho 95-988 (R) & 17 & 35.0 & $5.6 \mathrm{E}+2 \mathrm{~b}$ & $22 \mathrm{~b}$ & $10 \mathrm{~b}$ \\
\hline
\end{tabular}

${ }^{\text {w}}$ Means within a column followed by the same letter were not significantly different according to Tukey's test at $P \leq 0.05$.

x Total incidence of positive detections, critical threshold $\left(\mathrm{C}_{\mathrm{T}}\right)$ average value for systemically infected leaves, and $X$. albilineans $\mathrm{CFU} / \mathrm{ml}$ detected by qPCR.

${ }^{y}$ Conventional screening for resistance based on symptom severity during systemic infection. Disease severity score $=0$ to 100 , and incidence $=$ percentage of inoculated plants developing symptoms.

${ }^{\mathrm{z}}$ Two leaf scald susceptible (S) and two resistant (R) cultivars were compared.

Table 4. Comparison of Xanthomonas albilineans populations determined by SYBR Green quantitative polymerase chain reaction (qPCR) in systemically infected leaves of three susceptible and three resistant sugarcane cultivars with disease severity and incidence in field experiments ${ }^{\mathrm{w}}$

\begin{tabular}{|c|c|c|c|c|c|}
\hline \multirow[b]{2}{*}{ Cultivar $^{\mathrm{z}}$} & \multicolumn{3}{|c|}{ qPCR results ${ }^{x}$} & \multicolumn{2}{|c|}{ Conventional screening ${ }^{y}$} \\
\hline & Incidence $(\%)$ & $\mathrm{C}_{\mathrm{T}}$ value & $\mathrm{CFU} / \mathrm{ml}$ & Severity score & Incidence $(\%)$ \\
\hline НоCP 85-845 (S) & 100 & 21.7 & $8.5 \mathrm{E}+6 \mathrm{a}$ & $36.6 \mathrm{a}$ & $64 \mathrm{a}$ \\
\hline НоСР 89-846 (S) & 92 & 23.8 & $2.0 \mathrm{E}+6 \mathrm{a}$ & $35.7 \mathrm{a}$ & $40 \mathrm{a}$ \\
\hline НоСР 00-950 (S) & 80 & 23.9 & $1.8 \mathrm{E}+6 \mathrm{a}$ & $20.4 \mathrm{ab}$ & $38 \mathrm{a}$ \\
\hline LCP 85-384 (R) & 8 & 34.8 & $1.3 \mathrm{E}+3 \mathrm{~b}$ & $1.1 \mathrm{~b}$ & $2 \mathrm{~b}$ \\
\hline Ho 95-988 (R) & 46 & 32.1 & $6.1 \mathrm{E}+3 \mathrm{~b}$ & $2.2 \mathrm{~b}$ & $5 \mathrm{~b}$ \\
\hline НоСР 96-540 (R) & 23 & 33.3 & $3.0 \mathrm{E}+3 \mathrm{~b}$ & $0.3 \mathrm{~b}$ & $2 b$ \\
\hline
\end{tabular}

${ }^{\text {w }}$ Means within a column followed by the same letter were not significantly different according to Tukey's test at $P \leq 0.05$.

${ }^{x}$ Total incidence of positive detections, critical threshold $\left(\mathrm{C}_{\mathrm{T}}\right)$ average value for systemically infected leaves, and X. albilineans $\mathrm{CFU} / \mathrm{ml}$ detected by qPCR.

${ }^{y}$ Conventional screening for resistance based on symptom severity during systemic infection. Disease severity score $=0$ to 100 and incidence $=$ percentage of inoculated plants developing symptoms.

${ }^{\mathrm{z}}$ Three leaf scald susceptible $(\mathrm{S})$ and three resistant $(\mathrm{R})$ cultivars were compared. 
tions detected by qPCR corresponded with disease incidence and severity in a comparison of three leaf-scald-resistant and three susceptible cultivars in inoculated field experiments (Table 4). Incidence of positive detection by qPCR was 80 to $100 \%$ for the susceptible cultivars compared with 8 to $46 \%$ for the resistant cultivars. Quantified bacterial populations were three orders of magnitude higher in systemically infected leaves of the three susceptible compared with the resistant cultivars. With conventional resistance screening, the incidence of plants with systemic infection symptoms was 38 to $64 \%$ compared with 2 to $5 \%$ for the susceptible and resistant cultivars, respectively, while disease severity scores were 20.4 to 36.6 for the susceptible cultivars compared with 0.3 to 2.2 for the resistant cultivars.

\section{Discussion}

TaqMan and SYBR Green PCR assays were developed utilizing primers from the bacterium-specific albicidin toxin gene cluster for the detection and quantification of $X$. albilineans in sugarcane. These qPCR assays provided specific detection of $X$. albilineans without inhibition from sugarcane extracts. The qPCR assays were more sensitive than conventional PCR, and qPCR only requires $3 \mathrm{~h}$ to complete compared with 1 day for conventional PCR. The lower cost of SYBR Green PCR makes this method suitable for larger scale testing. TaqMan PCR could be utilized in situations requiring the most sensitive detection capability possible, such as quarantine operations and healthy seed-cane foundation or breeder nurseries. The ability to quantify bacterial populations provides the potential for use in comparative studies.

The first detection of leaf scald in Louisiana in 1993 (12) was part of a widespread outbreak of the disease in the Western Hemisphere (6). Studies of intraspecific variation in X. albilineans determined that isolates associated with the recent disease outbreak were all similar, as indicated by serological variation (serovar I) (22), pulsed-field gel electrophoresis group (haplotype B) (6), and repetitive element (rep)-PCR (15). Intraspecific variation was not detected in a large isolate group from Louisiana in the rep-PCR study, and biological variation, such as cultivar shifts from resistance to susceptibility, has not been detected in Louisiana. Only a few $X$. albilineans isolates were tested in this study but the low level of intraspecific variability detected in previous studies and the fact that the XALB1sequences used in the primer design are conserved among isolates (24) suggest that the PCR primers developed will detect all $X$. albilineans isolates currently occurring in Louisiana. Additional testing is needed to confirm that the qPCR assays will detect $X$. albilineans isolates in other serogroups or haplotypes.

The most effective method to prevent or control leaf scald is the development and planting of resistant cultivars (21). However, the erratic nature of symptom expression causes problems in accurately determining genotype resistance levels in inoculation tests conducted as part of a cultivar selection program. In addition, development of a useful resistance rating system based on qualitative traits is challenging.

Resistance to leaf scald is associated with the bacterial population at the shoot apex (23). Selective isolation of an antibioticresistant mutant strain revealed that even resistant clones are infected and colonized by $X$. albilineans; however, resistant genotypes exhibited a lower level of bacterial colonization, particularly in tissues at the shoot apex containing the apical meristem (20). This finding suggests that a qPCR assay could provide a less laborious, more rapid and accurate method to determine $X$. albilineans populations in inoculated plants for comparing resistance levels in clones in cultivar selection programs.

In this study, the $X$. albilineans population levels quantified by qPCR clearly distinguished known resistant from susceptible cultivars. These results agreed with the traditional measures for the assessment of resistance, disease incidence, and severity. As previously shown (23), the low and high bacterial populations detected in resistant and susceptible genotypes, respectively, were similar in inoculated plants in both greenhouse and field experiments. Com- parisons of $X$. albilineans populations quantified by qPCR in different tissues indicate that young leaves emerging from the apical meristem are the best tissue for detecting differences in $X$. albilineans populations among genotypes varying in level of resistance to leaf scald.

Precautions for successful inoculation by the decapitation method such as using a high inoculum concentration of an $X$. albilineans isolate recently obtained from symptomatic, infected tissue and avoiding exposure of the inoculum on the cut surface to UV light $(14,15,19)$ are essential to accomplish successful infection by $X$. albilineans. Additional research is needed to determine whether other factors such as environmental conditions prior to or following inoculation can limit initial or systemic infection, and determine the best timing of sampling after inoculation to maximize the detection of differences. Field experiments offer the advantage of natural conditions for plant growth and disease development but greenhouse experiments provide flexibility. Additional testing of more clones with differing levels of resistance under variable conditions in both the greenhouse and field is needed.

This study shows that $\mathrm{qPCR}$ is a highly sensitive and reliable method for the detection of $X$. albilineans that is capable of quantifying bacterial populations in infected sugarcane plants. The results suggest that $X$. albilineans quantification during systemic infection can provide a measure of the relative resistance or susceptibility to leaf scald among host genotypes. SYBR Green and TaqMan qPCRs have the potential to serve as powerful tools for understanding the basis of resistance and the effects of environmental conditions on development of bacterial populations, pathogen multiplication, disease development, and expression of resistance.

\section{Acknowledgments}

We thank M. Grisham and K. Warnke of the USDA-ARS Sugarcane Research Unit, Houma, LA for providing cultures of known microorganisms used for assay specificity testing.

\section{Literature Cited}

1. Alvarez, A. M., Schenck S., and Benedict, A. A. 1996. Differentiation of Xanthomonas albilineans strains with monoclonal antibody reaction patterns and DNA fingerprints. Plant Pathol. 43:344-349.

2. Champoiseau, P., Daugrois, J. H., Pieretti, I., Cociancich, S., Royer, M., and Rott, P. 2006. High variation in pathogenicity of genetically closely related strains of Xanthomonas albilineans, the sugarcane leaf scald pathogen, in Guadeloupe. Phytopathology 96:1081-1091.

3. Daugrois, J. H., Dumont, V., Champoiseau, P., Costet, L., Boisne-Noc, R., and Rott, P. 2003. Aerial contamination of sugarcane in Guadeloupe by two strains of Xanthomonas albilineans. Eur. J. Plant Pathol. 109:445-458.

4. Davis, M. J., Rott, P., Baudin, P., and Dean, J. L. 1994. Evaluation of selective media and immunoassays for detection of Xanthomonas albilineans, causal agent of sugarcane leaf scald disease. Plant Dis. 78:78-82.

5. Davis, M. J., Rott, P., and Monge, G. A. 1997. Multiplex polymerase chain reaction (PCR) for diagnosis of leaf scald and ratoon stunting diseases. Sugar Azucar 92:26.

6. Davis, M. J., Rott, P., Warmuth, C. J., Chatenet, M., and Baudin, P. 1997. Intraspecific genomic variation within Xanthomonas albilineans, the leaf scald pathogen. Phytopathology 87:316-324.

7. Garces, F. F. 2011. Comparative proteome and qPCR analysis of the sugarcane reaction to leaf scald caused by Xanthomonas albilineans. Ph.D. diss. Louisiana State University, Baton Rouge.

8. Garces, F. F., Balladarez, C., Quiridumbay, G., and Muñoz, C. 2005. Diagnosis of leaf fleck, leaf scald, mosaic, ratoon stunting disease and yellow leaf of sugarcane in commercial fields and quarantine in Ecuador. Proc. Int. Soc. Sugar Cane Technol. 25:695-700.

9. Ginzinger, D. G. 2002. Gene quantification using real-time quantitative PCR: An emerging technology hits the mainstream. Exp. Hematol. 30:503512 .

10. Guzman, M. L., Angel, J. C., Victoria, J. I., and Alvarez, A. 1997. Diagnostico de la escaldadura de la hoja en cana de azucar. Fitopatol. Colomb. 21:10-17.

11. Higuchi, R., Fockler, C., Dollingger, G., and Waterson, R. 1993. Kinetic PCR analysis: Real-time monitoring of DNA amplification reactions. Biotechnology 11:1026-1030.

12. Hoy, J. W., and Grisham, M. P. 1994. Sugarcane leaf scald distribution, symptomatology, and effect on yield in Louisiana. Plant Dis. 78:1083-1087.

13. Jaufeerally-Fakim, Y., Autrey, J. C., Toth, I., Daniels, M., and Dookun, A 2002. Amplification polymorphism among Xanthomonas albilineans strains, using a single oligonucleotide primer. Eur. J. Plant Pathol. 108:121130. 
14. Koike, H. 1965. Aluminum-cap method for testing sugarcane varieties against leaf scald disease. Phytopathology 55:317-319.

15. Lopes, S. A., Damann, K. E., and Grelen, L. B. 2001. Xanthomonas albilineans diversity and identification based on rep-PCR fingerprints. Curr. Microbiol. 42:155-159.

16. Pan, Y. B., Grisham, M. P., and Burner, D. M. 1997. A polymerase chain reaction protocol for the detection of Xanthomonas albilineans, the causal agent of sugarcane leaf scald disease. Plant Dis. 81:189-194.

17. Pan, Y. B., Grisham, M. P., Burner, D. M., Legendre, B. L., and Wei, Q. 1999. Development of polymerase chain reaction primers highly specific for Xanthomonas albilineans, the causal bacterium of sugarcane leaf scald disease. Plant Dis. 83:218-222.

18. Renier, A., Vivien, E., Cociancich, S., Letourmy, P., Perrier, X., Rott, P. C., and Royer, M. 2007. Substrate specificity-conferring regions of the nonribosomal peptide synthetase adenylation domains involved in albicidin pathotoxin biosynthesis are highly conserved within the species Xanthomonas albilineans. Appl. Environ. Microbiol. 73:5523-5530.

19. Ricaud, C., and Ryan, C. C. 1989. Leaf scald. Pages 39-38 in: Diseases of Sugarcane. Major Diseases. C. Ricaud, B. T. Egan, A. G. Gillaspie, Jr., and C. G. Hughes, eds. Elsevier, Amsterdam.

20. Rott, P., Abel, M., Soupa, D., Feldman, P., and Letourmy, P. 1994. Population dynamics of Xanthomonas albilineans in sugarcane plants as determined with an antibiotic resistant mutant. Plant Dis. 78:241-247.

21. Rott, P., and Davis, M. J. 2000. Leaf scald. Pages 38-44 in: A Guide to Sugarcane Diseases. P. Rott, R. A. Bailey, J. C. Comstock, B. J. Croft, and
A. S. Saumtally, eds. CIRAD-ISSCT, Paris.

22. Rott, P., Davis, M. J., and Baudin, P. 1994. Serological variability in Xanthomonas albilineans, causal agent of leaf scald disease of sugarcane. Plant Pathol. 43:344-349.

23. Rott, P., Mohamed, I. S., Klett, P., Soupa, D., de Saint-Albin, A., Feldmann, P., and Letourmy, P. 1997. Resistance to leaf scald disease is associated with limited colonization of sugarcane and wild relatives by Xanthomonas albilineans. Phytopathology 87:1202-1213.

24. Royer, M., Costet, L., Vivien, E., Bes, M., Cousin, A., Damais, A., Pieretti, I., Savin, A., Megessier, S., Viard, M., Frutos, R., Gabriel, D. W., and Rott, P. C. 2004. Albicidin pathotoxin produced by Xanthomonas albilineans is encoded by three large PKS and NRPS genes present in a gene cluster also containing several putative modifying, regulatory, and resistance genes. Mol. Plant-Microbe Interact. 17:414-427.

25. Saumtally, A. S., and Dookun, A. 2004. Leaf scald of sugarcane: a disease of worldwide importance. Pages 65-76 in: Sugarcane Pathology. Volume III: Bacterial and Nematode Diseases. G. P. Rao, A. S. Saumtally, and P. Rott, eds. Science Publishers, Inc., Enfield, NH.

26. Victoria, J. I., Guzmán Romero, M. L., Garcés, F. F., and Jaramillo, A. D 1998. Pathogen-free seed cane production and its impact on a commercial scale. Proc. Int. Soc. Sugar Cane Technol. 23:390-397.

27. Wang, Z. K., Comstock, J., Hatziloukas, C. E., and Schaad, N. W. 1999 Comparison of PCR, BIO-PCR, DIA, ELISA and isolation on semi-selective medium for detection of Xanthomonas albilineans, the causal agent of leaf scald of sugarcane. Plant Pathol. 48:245-252. 